\title{
Morphological, histopathological and molecular characterization of Thelohanellus muscularis n. sp. (Cnidaria: Myxosporea) infecting head muscles of Labeo rohita from Ranjit sagar wetland, Punjab (India)
}

\author{
Harpreet Kaur ${ }^{1 *}$, Aditya Gupta ${ }^{2}$ \\ 'Department of Zoology, Panjab University, Chandigarh-160014, Chandigarh, India. \\ ${ }^{2}$ Department of Zoology and Environmental Sciences, Punjabi University, Patiala- 147002, Punjab, India.
}

\begin{tabular}{|c|c|}
\hline ARTICLE INFO & ABSTRACT \\
\hline $\begin{array}{l}\text { Article history: } \\
\text { Received on: } 13 / 07 / 2016 \\
\text { Revised on: } 06 / 09 / 2016 \\
\text { Accepted on: } 04 / 09 / 2016 \\
\text { Available online: } 20 / 01 / 2017\end{array}$ & $\begin{array}{l}\text { In the present study, a new species, Thelohanellus muscularis } \mathrm{n} \text {. sp. infecting head muscles of Labeo rohita } \\
\text { (Family Cyprinidae) from Ranjit Sagar Wetland, Punjab, India has been described on the basis of its morphology, } \\
\text { histopathology and molecular analyses. The plasmodia were visible with the naked eye in the head muscles } \\
\text { (opercular region) as round whitish bodies. The size of plasmodia ranged } 0.6-0.8 \mathrm{~mm} \text { each containing about } 80 \text { - } \\
100 \text { myxospores. The myxospores were pyriform in shape, blunt at the anterior end measuring } 9.20 \pm 0.28 \mu \mathrm{m} \times\end{array}$ \\
\hline $\begin{array}{l}\text { Key words: } \\
18 \mathrm{~S} \text { rDNA; muscles; } \\
\text { Phylogenetic analysis; Labeo } \\
\text { rohita; India. }\end{array}$ & $\begin{array}{l}4.0 \pm 0.15 \mu \mathrm{m} \text { in size. Polar capsule was elongately pyriform measuring } 5.85 \pm 0.08 \mu \mathrm{m} \times 3.10 \pm 0.11 \mu \mathrm{m} \text { in size. } \\
\text { The amplified } 18 \mathrm{~S} \text { rDNA product was } 900 \text { bp (accession number KT387308). The phylogenetic analysis indicated } \\
99 \% \text { homogeneity with three other thelohanelloid species recorded from freshwater fishes in India, i.e., T. filli } \\
\text { (KR340464) infecting gills of Labeo rohita, T. sp. RA (KR423868) infecting gills of Catla catla and T. jiroveci } \\
\text { (KJ476885) infecting gills of Labeo rohita. The prevalence of infection was } 25 \% \text {. The plasmodia and numerous } \\
\text { myxospores were recorded in intermuscular fibrillar space in histological sections. Phylogenetic analyses } \\
\text { elucidated relationship of the newly described Thelohanellus muscularis to other Thelohanellus species and } \\
\text { supported its position as an independent species. }\end{array}$ \\
\hline
\end{tabular}

\section{INTRODUCTION}

The genus Thelohanellus Kudo, 1933 [1] is the sixth most speciose myxozoan after Myxobolus, Myxidium, Henneguya, Ceratomyxa and Chloromyxum with 108 nominal species [2]. Species belonging to Thelohanellus Kudo, 1933 are typically histozoic (rarely coelozoic) infecting almost every organ of the fish. Myxospores are tear shaped or pyriform to broadly ellipsoidal. A single polar capsule is present, either pyriform or tear shaped [3]. Most of the species of Thelohanellus have been reported to be non pathogenic to their hosts, however, $T$. wuhanensis [4], T. hovorkai [5], T. nikolskii [6], T. kitauei [7], T. wangi [8], T. bifurcata [9], T. filli [10] have been shown to cause severe morbidity and mortality of infected fish [11-14]. Ranjit Sagar Wetland is located on river Ravi which is about $24 \mathrm{~km}$ upstream of Madhopur Headworks in Gurdaspur district, Punjab. It is a manmade, riverine and lacustrine wetland with freshwater ecology. It lies at an altitude of about $540 \mathrm{msl}$ at $32^{\circ} 26^{\prime} 30^{\prime \prime} \mathrm{N}$ Latitude and $75^{\circ} 43^{\prime} 30 \mathrm{E}$ Longitude and is spread over an area

* Corresponding Author

E-mail: harpreetbimbra @gmail.com of $87.60 \mathrm{sq} \mathrm{km} \mathrm{[15].} \mathrm{The} \mathrm{area} \mathrm{of} \mathrm{different} \mathrm{states} \mathrm{falling} \mathrm{under}$ reservoir is Punjab (3\%), Himachal Pradesh (82\%) and Jammu \& Kashmir (15\%). The Ranjit Sagar Wetland is a cold water wetland and occupying largest catchment area (6086 sq. km.) as compared to the other wetlands in the state. For identification of myxosporeans the information generated from molecular phylogeny in addition to morphological traits greatly help in revealing the cryptic and species complexes along with their phylogeographic origin $[16,17]$. In North India, many species of myxozoan parasites have been recorded from freshwater fishes in wetlands and aquaculture ponds in Punjab [18-39].

\section{MATERIAL AND METHODS}

\subsection{Collection and Microscopy}

Live specimens of Labeo rohita $(n=48)$ with average length of $15-20 \mathrm{~cm}$ were procured from the various catchment sites of Ranjit Sagar Wetland, Punjab, India. Plasmodia present within the head muscle fibres (in opercular) region were removed, teased on a slide and examined under phase contrast microscope (Magnus MLX) to study the myxospore morphology. 


\subsection{Histopathology}

The muscles containing plasmodia were cut into small pieces and fixed in Bouin's fixative. Tissue samples were dehydrated in ascending grades of ethanol, cleared in xylene, embedded in paraffin wax, sectioned at 6-7 $\mu \mathrm{m}$ thickness, stained with Luna's staining method [40] and photographed.

\subsection{DNA extraction, PCR amplification and sequencing}

The myxospores were collected and fixed in absolute alcohol for molecular and phylogenetic analysis. The parasite DNA was extracted using the DNeasy Blood \& Tissue Kit (Qiagen) following the manufacturer's instructions. The primers My1F (CTAATCCCGGTAACGAACGA) My10R (CGTCCTCGCAACAAACTGTA) were used for the amplification of 18S rDNA using a Eppendorf Master Cycler Pro $\mathrm{S}$. The PCR was carried out, according to [41] at the final volume of $25 \mu \mathrm{l}$ using the primers which amplified $900 \mathrm{bp}$ of the $18 \mathrm{~S}$ rDNA gene.

The amplification reactions were conducted with $45 \mathrm{ng}$ of genomic DNA, $12.5 \mu \mathrm{l}$ of $1 \times$ reaction buffer (Himedia), $1.0 \mu \mathrm{l}$ of each primers, $1.0 \mu \mathrm{l}$ of total DNA and $10.5 \mu \mathrm{l}$ of nuclease free water. Amplification was done by initial denaturation at $95^{\circ} \mathrm{C}$ for 3 min, followed by 34 cycles of denaturation at $95^{\circ} \mathrm{C}$ for $30 \mathrm{~s}$, annealing of primers at $57^{\circ} \mathrm{C}$ for $30 \mathrm{~s}$, extension at $72^{\circ} \mathrm{C}$ for $1 \mathrm{~min}$ $20 \mathrm{~s}$.

The final extension was at $72^{\circ} \mathrm{C}$ for $10 \mathrm{~min}$. The PCR products were analyzed on a $2 \%$ agarose gel and size was estimated by comparison with the 100 bp Plus DNA Ladder. The amplified product was commercially sequenced at Molecular Diagnostic \& Research Laboratories, Chandigarh (India).

\subsection{Phylogenetic analysis}

The phylogenetic analysis was done on a selection of $18 \mathrm{~S}$ rDNA sequences that comprised the new sequence (KT387308) and 18 additional sequences from closely related sequences showing $88 \%$ homogeneity or above in NCBI GenBank database using the basic local alignment tool [42]. Ceratonova shasta (AF001579) isolated from Oncorhynchus mykiss was taken as an outgroup. Genetic distance analyses were conducted using the Kimura 2-parameter model [43] in MEGA6 software [44]. Included codon positions were $1 \mathrm{st}+2 \mathrm{nd}+3 \mathrm{rd}+$ Noncoding. All positions containing gaps and missing data were eliminated. The Bayesian phylogenetic analysis was conducted using MrBayes v3.2.2 [45].

Sequence alignment was performed by Multiple Sequence Comparison by Log-Expectation (MUSCLE). The tree was generated using Maximum- Likelihood having 1000 bootstrap values and was proportional to the number of substitutions per site.

\section{RESULTS}

\subsection{Vegetative stages}

Plasmodia minute, round, creamish-white, measure 0.6$0.8 \mathrm{~mm}$ in diameter attached to the muscle fibres of the opercular region, 80-100 myxospores per plasmodium. Clinical signs on the muscles were apparent showing pale appearance (Figure 1).
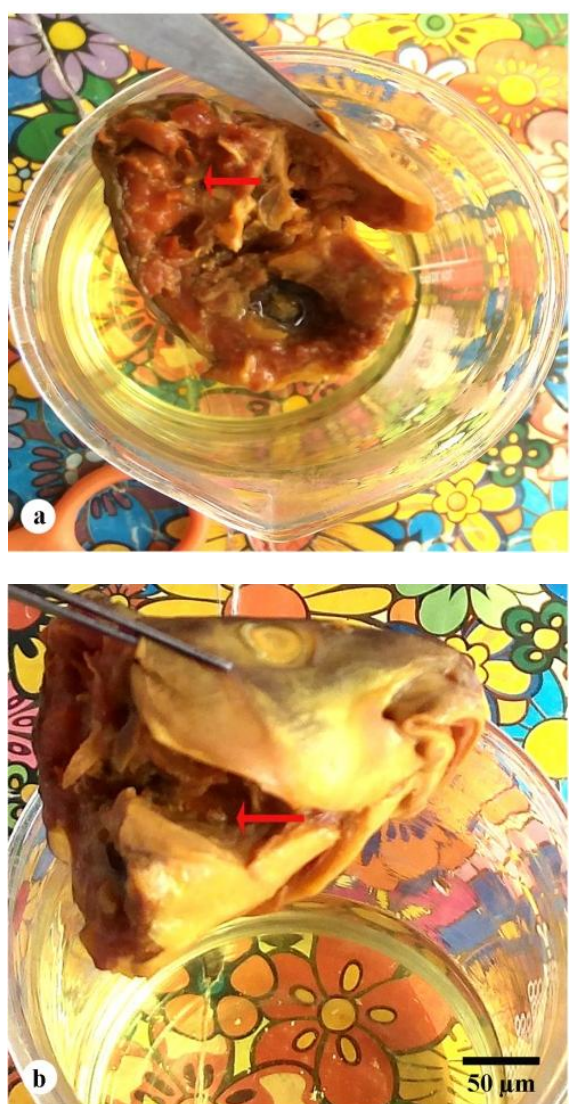

Fig. 1: (a \& b) Infected head of Labeo Rohita showing plasmodia of $\mathrm{T}$. muscularis n. sp. Located in the muscles.

\subsection{Mature myxospores}

Myxospores measure $9.20 \times 4.00 \mu \mathrm{m}$, small-sized pyriform in valvular view having bluntly pointed anterior end and rounded posterior end. Shell valves thin, smooth, symmetrical and measure $0.16 \mu \mathrm{m}$ in thickness. Sutural line straight. Parietal folds absent. Polar capsule elongately pyriform, eccentrically placed in the myxospore body cavity. Polar capsule occupying more than half of the myxospore body cavity, measure $5.85 \times 3.10 \mu \mathrm{m}$. Polar filament form 7-9 coils arranged perpendicular to the polar capsule axis. Sporoplasm agranular, homogenous occupying whole of the extracapsular space behind the polar capsule and contain two nuclei and an iodinophilous vacuole (Figure 2, Table 1).

Table 1: Measurements $(\mu \mathrm{m})$ and ratio of T. muscularis $\mathrm{n}$. sp. isolated from head muscles of Labeo rohita (LS length of spore, WS width of spore, LPC length of polar capsule, WPC width of polar capsule, SD standard deviation, CV coefficient of varience).

\begin{tabular}{lclll}
\hline Characters & Range & Mean Values & SD & CV \\
\hline LS & $9.15-9.25$ & 9.20 & 0.07 & 0.00 \\
WS & $3.92-4.08$ & 4.00 & 0.11 & 0.01 \\
LPC & $5.70-5.98$ & 5.98 & 0.19 & 0.03 \\
WPC & $3.05-3.15$ & 3.10 & 0.07 & 0.00 \\
LS/WS & & 2.30 & & \\
Number of filament turns & & $7-9$ & & \\
Parietal folds & & Absent & & \\
\hline
\end{tabular}




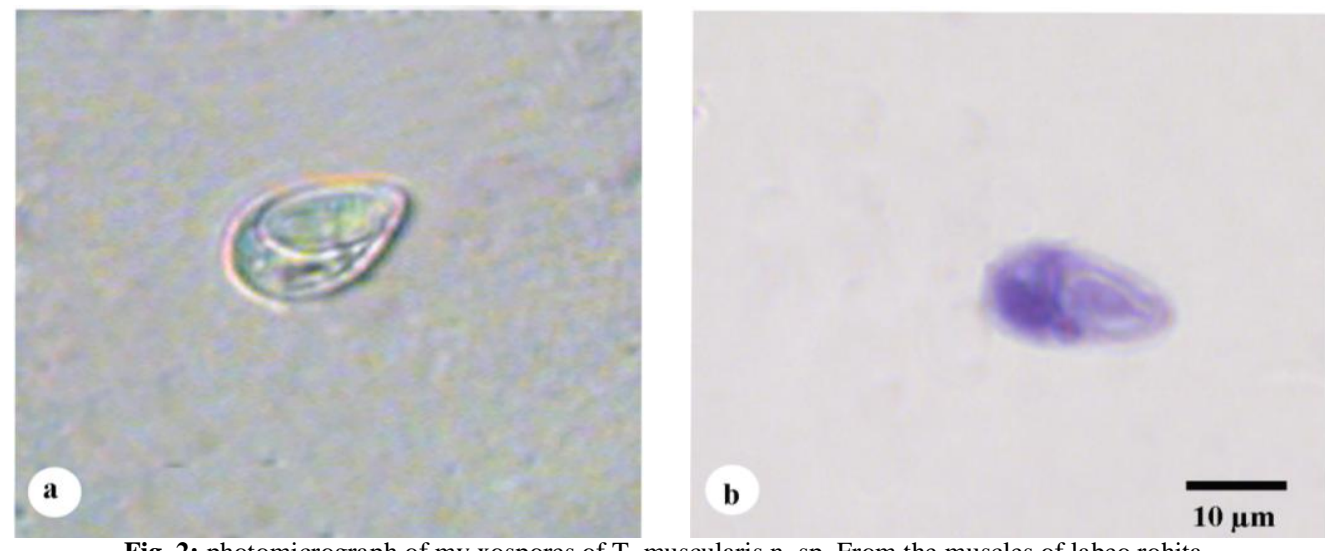

Fig. 2: photomicrograph of my xospores of T. muscularis n. sp. From the muscles of labeo rohita.

a. Fresh my xospore, My xospore stainec in iron- haematoxylin.

\subsection{Taxonomic summary}

Type-host: Labeo rohita vern rohu, (Family: Cyprinidae)

Type-locality: Ranjit Sagar wetland, Punjab, India.

Site of infection: Head muscles.

Type materials: Slide no. M/ZN/16.2.2015 and M/IH/16.2.2015, Parasitology Laboratory, Department of Zoology, Panjab University, Chandigarh (India).

Parasite frequency index (PFI): 25\% (12/48)

Clinical symptomatology: Moderately symptomatic, whitish pustules on the muscles and mucous laden body.

Etymology: The specific epithet 'muscularis' has been given after the name of the tissue location within the host.

\subsection{Histopathology}

The plasmodia were located in the intermuscular space and were $0.8-1.0 \mathrm{~mm}$ in size, forming whitish pustules, cylindrical in shape, containing about 80-100 myxospores. Histologically, masses of myxospores released from disintegrated muscle cells were found between the intact muscle fibres followed by degeneration, necrosis and atrophy. There was accumulation of myxospores in the intermuscular fibrillar space as revealed in transverse sections with myonecrosis along the epaxial end adjacent to vertebral column.

\subsection{Phylogenetic analysis}

The phylogenetic tree based on the final edited alignment with Maximum- Likelihood showed T. muscularis n. sp. in a separate clade with a bootstrap value of 93 comprising $T$. seni, $T$. rohitae, $T$. bifurcata, $T$. jiroveci, $T$. filli, $T$. sp. HK and $T$. sp. RA infecting cyprinids carp from India. The out- group Ceratonova shasta phylogenetically clustered distinctly as a separate lineage (Figure 5). Moreover, estimates of evolutionary pair- wise divergence among the sequences of $T$. seni, $T$. rohitae, $T$. bifurcata, T. jiroveci, T. filli, T. sp. HK and T. sp. RA were 0.03 , $0.05,0.01,0.0,0.0,0.05$ and 0.0 respectively (Figure 6). The nucleotide frequencies were $26.73 \%$ (A), $24.21 \%$ (T/U), $21.61 \%$ (C) and $27.46 \%(\mathrm{G})$. The transition/transversion rate ratios are $\mathrm{K} 1=3.715$ (purines) and $\mathrm{K} 2=5.369$ (pyrimidines).
The best fit substitution model for constructing the phylogenetic tree was $\mathrm{K} 2+\mathrm{G}$ having the lowest Bayesian score of 3546.077 followed by the Gamma distribution among 5 categories was $0.05,0.24,0.58,1.17$ and 2.96 substitutions per site.

All positions containing gaps and missing data were eliminated. Tajima's neutrality test for the nucleotide mutation was also done. The $\mathrm{D}$ value was less than 0 and was found to be 1.766589 meaning some of the alleles were present at high frequencies indicating high genetic diversity among myxosporeans.

\section{DISCUSSION}

\subsection{Morphological comparison}

The present species was morphologically compared with previously reported Thelohanellus species from Indian subcontinent (Table 2).

The present species was closely compared with other Thelohanellus species infecting muscles i. e. T. gangeticus [56] infecting muscles of Cheila bacaila and T. ophthalmicus [57] infecting eye muscles of Catla catla and was much smaller in size. In addition, the myxospores of $T$. seni $(13.71 \mu \mathrm{m}), T$. otebike $(14.85 \mu \mathrm{m}), T$. catlae $(20.4 \mu \mathrm{m})$, T. carassii $(17.0 \mu \mathrm{m}), T$. caudatus $(13.8 \mu \mathrm{m}), T$. boggoti $(11.5 \mu \mathrm{m})$, T. filli $(27.08 \mu \mathrm{m})$ and T. jiroveci $(35.0 \mu \mathrm{m})$ were much longer than the present species $(9.20 \mu \mathrm{m})$. Furthermore, the present species lacked parietal folds hence differed from $T$. parastromataei and $T$. misgurni in which distinct parietal folds were present. The myxospores of the present species also lacked a distinct neck, hence differed from $T$. boggoti and $T$. thaili having distinct neck.

The myxospores of $T$. muscularis $\mathrm{n}$. sp. were characterized in having small-sized pyriform shape in valvular view with bluntly pointed anterior end and rounded posterior end, in this respect, it differed from T. globulosa in which myxospores were ovoid to spherical in shape. In addition to this, the present species was compared with $T$. batae and T. wallogoi, but different in having eccentrically placed polar capsule as compared to the terminal or central position in the later two. 
Table 2: Comparative description of T. muscularis $\mathrm{n}$. sp. with morphologically similar species (measurements in micrometer).

\begin{tabular}{|c|c|c|c|c|c|c|c|c|}
\hline Species & Host & Infected organ & Country & LS & WS & LPC & WPC & $\begin{array}{c}\text { No. of } \\
\text { filament } \\
\text { turns }\end{array}$ \\
\hline T. muscularis n. sp. (present study) & Labeo rohita & muscles & India & 9.20 & 4.00 & 5.85 & 3.10 & $7-9$ \\
\hline T. misgurni Kudo, 1933 & $\begin{array}{l}\text { Misgurnus } \\
\text { anguillicaudatus }\end{array}$ & Gall bladder & Japan & 14.75 & 6.65 & 6.9 & 3.7 & - \\
\hline T. catlae Chakravarty \& Basu, 1948 & Catla catla & Gills & India & 20.4 & 11.5 & 10.7 & 13.9 & $9-10$ \\
\hline T. seni Chakravarty \& Basu, 1948 & Catla catla & branchiae & India & 13.71 & 8.56 & 6.42 & 4.52 & $7-8$ \\
\hline T. carassii Akhmerov, 1960 & Carassius auratus gibelio & Gills & Russia & 17.0 & 10.25 & 7.75 & 5.7 & - \\
\hline T. boggoti Qadri, 1962 & Labeo boggot & Gills & India & 11.5 & 6.8 & 6.2 & 3.8 & $10-11$ \\
\hline T. batae Lalitha Kumari, 1969 & Labeo bata & gill filaments & India & 12.3 & 6.2 & 7.7 & 3.0 & $3-4$ \\
\hline T. otebike Allamuratov \& Iskov, 1970 & Paracobitis longicauda & Gills & Uzbekistan & 14.85 & 7.1 & 7.95 & 3.55 & - \\
\hline T. jiroveci Kundu \& Haldar, 1981 & Labeo rohita, Labeo bata & Gills & India & 35.0 & 13.0 & 18.4 & 7.0 & $10-12$ \\
\hline T. wallagoi Sarkar, 1985 & Wallago attu & gall bladder & India & 9.25 & 4.8 & 5.4 & 2.7 & $4-5$ \\
\hline $\begin{array}{l}\text { T. parastromataei Narasimhamurti et al., } \\
1990\end{array}$ & Parastromataeus niger & gall bladder & India & 11.18 & 9.46 & 8.6 & 6.88 & $6-7$ \\
\hline T. caudatus Pagarkar \& Das, 1993 & Labeo rohita & $\begin{array}{l}\text { caudal and anal } \\
\text { fins }\end{array}$ & India & 13.8 & 9.0 & 7.0 & 5.07 & $6-7$ \\
\hline T. globulosa Singh \& Kaur, 2012 & Cirrhinus reba & caudal fin & India & 11.67 & 7.9 & 5.3 & 4.8 & $4-5$ \\
\hline T. thaili Singh \& Kaur, 2012 & Catla catla & Gills & India & 11.67 & 7.22 & 7.30 & 4.40 & $4-5$ \\
\hline T. filli Kaur et al., 2014 & Labeo rohita & Gills & India & 27.08 & 10.56 & 16.63 & 8.25 & $10-11$ \\
\hline
\end{tabular}

Table 3: Homogeneity of 18S rRNA gene sequences of Thelohanellus muscularis n. sp. (Accession number KT387308) and other myxobolids and related taxa available in NCBI GenBank.

\begin{tabular}{|c|c|c|c|c|c|c|}
\hline Myxozoan & $\begin{array}{c}\text { Accession } \\
\text { number }\end{array}$ & Organ infected & Host & Country & $\begin{array}{l}\text { Query } \\
\text { cover }\end{array}$ & $\begin{array}{c}\text { Homogeneity (\%) } \\
\text { to T. muscularis n. sp. } \\
(\text { KT387308) }\end{array}$ \\
\hline T. filli & KR340464 & Gills & Labeo rohita & India & 99 & $1668 / 1668(99)$ \\
\hline T. sp. RA & KR423868 & Gills & Cirrhinus mrigala & India & 99 & $1629 / 1629(99)$ \\
\hline T. jiroveci & KJ476885 & Gills & L. rohita & India & 98 & $1611 / 1611(99)$ \\
\hline T. bifurcata & KJ476886 & Gills & L. rohita & India & 99 & $1594 / 1594(98)$ \\
\hline T. T. seni & KJ476884 & Gills & L. rohita & India & 98 & $1580 / 1580(98)$ \\
\hline Thel T. rohitae & KF170927 & Gills & L. rohita, L. bata & India & 98 & $1480 / 1480(96)$ \\
\hline T. sp. HK & KP792568 & Gills & C. catla & India & 93 & $1423 / 1423(97)$ \\
\hline Thelo T. catlae & KJ476881 & Gills & C. catla & India & 98 & $1319 / 1319(93)$ \\
\hline$T$. sp. KLT & KM401440 & skin, gill arch & L. rohita & Myanmar & 98 & $1219 / 1219(91)$ \\
\hline T. kitauei & HM624024 & intestine & Cyprinus carpio пиdus & South Korea & 98 & $1214 / 1214(91)$ \\
\hline Thelo T. wuhanensis & HQ613410 & Skin & Carassius auratus gibelio & China & 98 & $1212 / 1212(91)$ \\
\hline Thelo T. nikolskii & GU165832 & Fins & C. carpio & China & 97 & 1098/1098 (89) \\
\hline T. macrovacuolaris & KU160631 & Palate & C. carpio & China & 73 & $795 / 795(88)$ \\
\hline Mухо $\quad$ T. hovorkai & DQ231155 & Abdomen & C. carpio & Hungary & 70 & $778 / 778(89)$ \\
\hline T. sp. YL & KC843624 & Skin & C. auratus gibelio & China & 61 & 737/737 (96) \\
\hline T. sp. JZ & JX458816 & Gills & C. auratus gibelio & China & 80 & $723 / 1215(96)$ \\
\hline Myxobolus margitae & EU598803 & Gills & Alburnus alburnus & Hungary & 48 & $723 / 723(96)$ \\
\hline Ceratonova shasta & AF001579 & intestinal tissues & Oncorhynchus mykiss & USA & & Outgroup \\
\hline
\end{tabular}

\subsection{Molecular comparison}

The primer sets My1F and MY10R successfully amplified the 18S rRNA gene of size $900 \mathrm{bp}$ (Figure 3). The edited nucleotide sequence obtained from myxospores of T. muscularis $\mathrm{n}$. sp. were deposited in the GenBank under the accession number of KT387308. The BLASTn analysis of T. muscularis $\mathrm{n}$. sp. showed maximum homogeneity with T. filli (KR340464; 99\% similarity over $1668 \mathrm{bp}$ ) infecting the gills of $L$. rohita from India, T. sp. RA (KR423868; 99\% similarity over 1629 bp) infecting the gills of C. mrigala from India, T. jiroveci (KJ476885; 99\% similarity over $1611 \mathrm{bp}$ ) infecting the gills of $L$. rohita from India, T. bifurcata
(KJ476886; 90\% similarity over $1594 \mathrm{bp)} \mathrm{infecting} \mathrm{the} \mathrm{gills} \mathrm{of} L$. rohita from India and T. seni (KJ476884; 98\% similarity over 1580 bp) infecting gills of Labeo rohita from India (Table 3). The high homogeneity values between T. muscularis $\mathrm{n}$. sp. and above mentioned species could be due to the same order/family of host and same geographical location. The Tajima's neutrality test suggests that some of the alleles were present at high frequencies indicating significant genetic diversity among myxosporeans.

In view of the above differences, the present species under study has been proposed as new to the science and named as T. muscularis $\mathrm{n}$. sp. through this communication. 


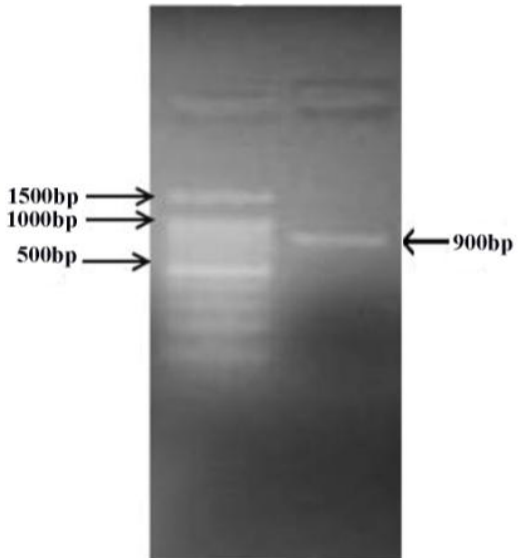

Fig. 3: Agarose gel (2\%) showing $18 \mathrm{~S}$ Rdna gene amplification of T. muscularis n. sp. From Labeo rohita.

a

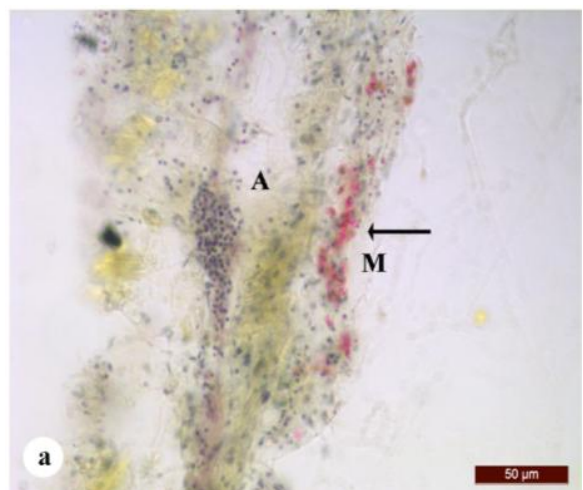

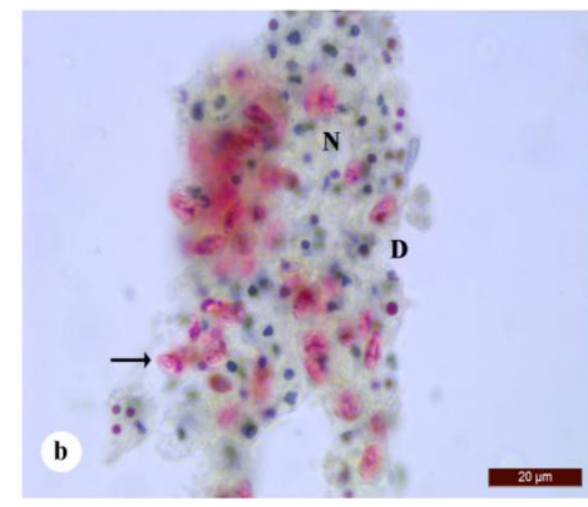

Fig. 4: Longitudinal section of the muscles of Labeo rohita infected with my xospores of T. muscularis n. sp. ( A- atrophy of cells, M-myxospores, D-degeneration of cells, N-necrosis) a-400x, b- 1000x.

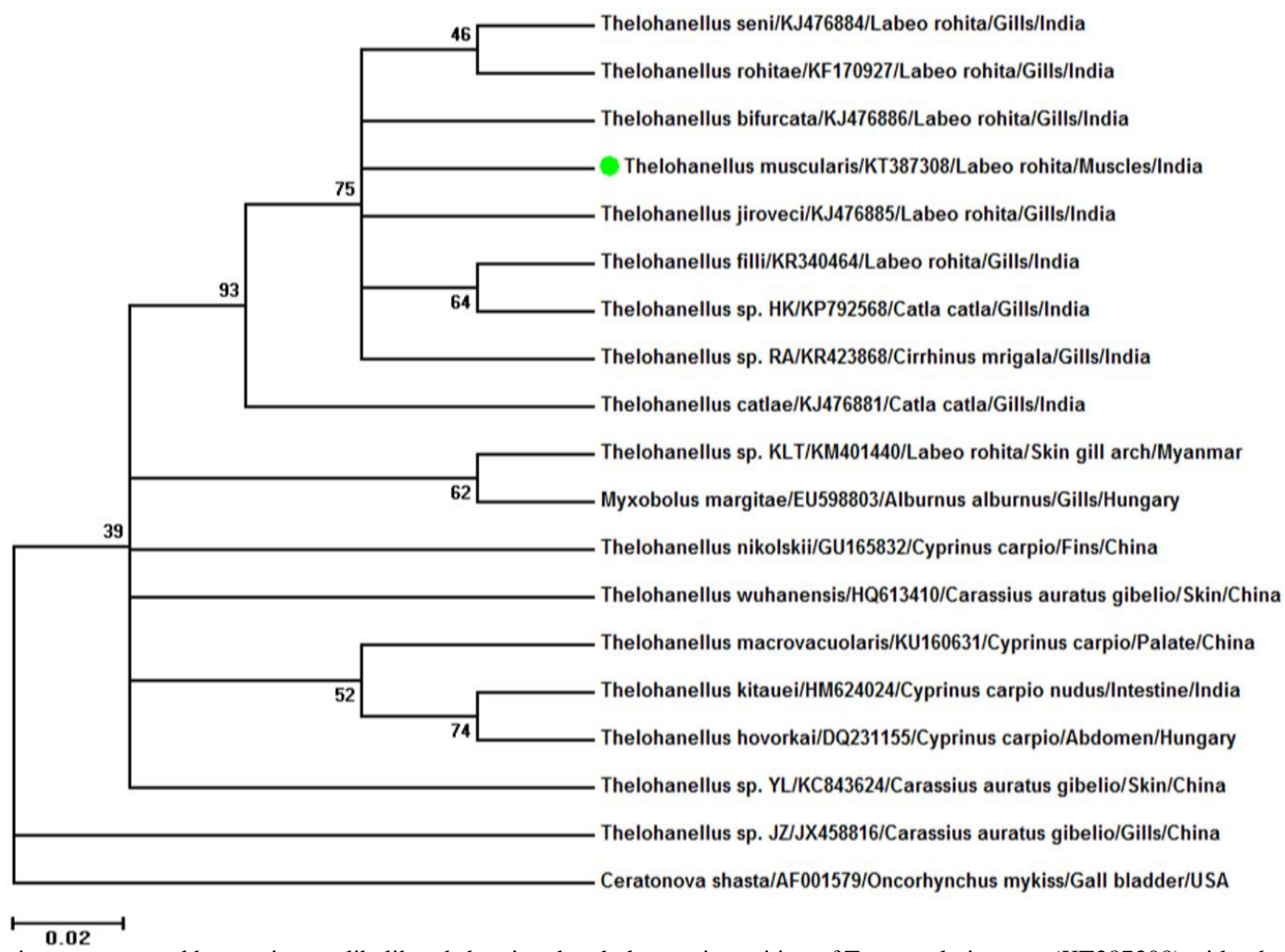

Fig. 5: Phylogenetic tree generated by maximum- likelihood showing the phylogenetic position of T. muscularis n. sp. (KT387308) with other myxosporeans. Genbank accession numbers, organ, host and country names are given and number above nodes indicates boot-strap confidence values. Ceratonova shashta was taken as the out-group. Scale bar: amount of inferred evolutionary change along the branch lengths. 


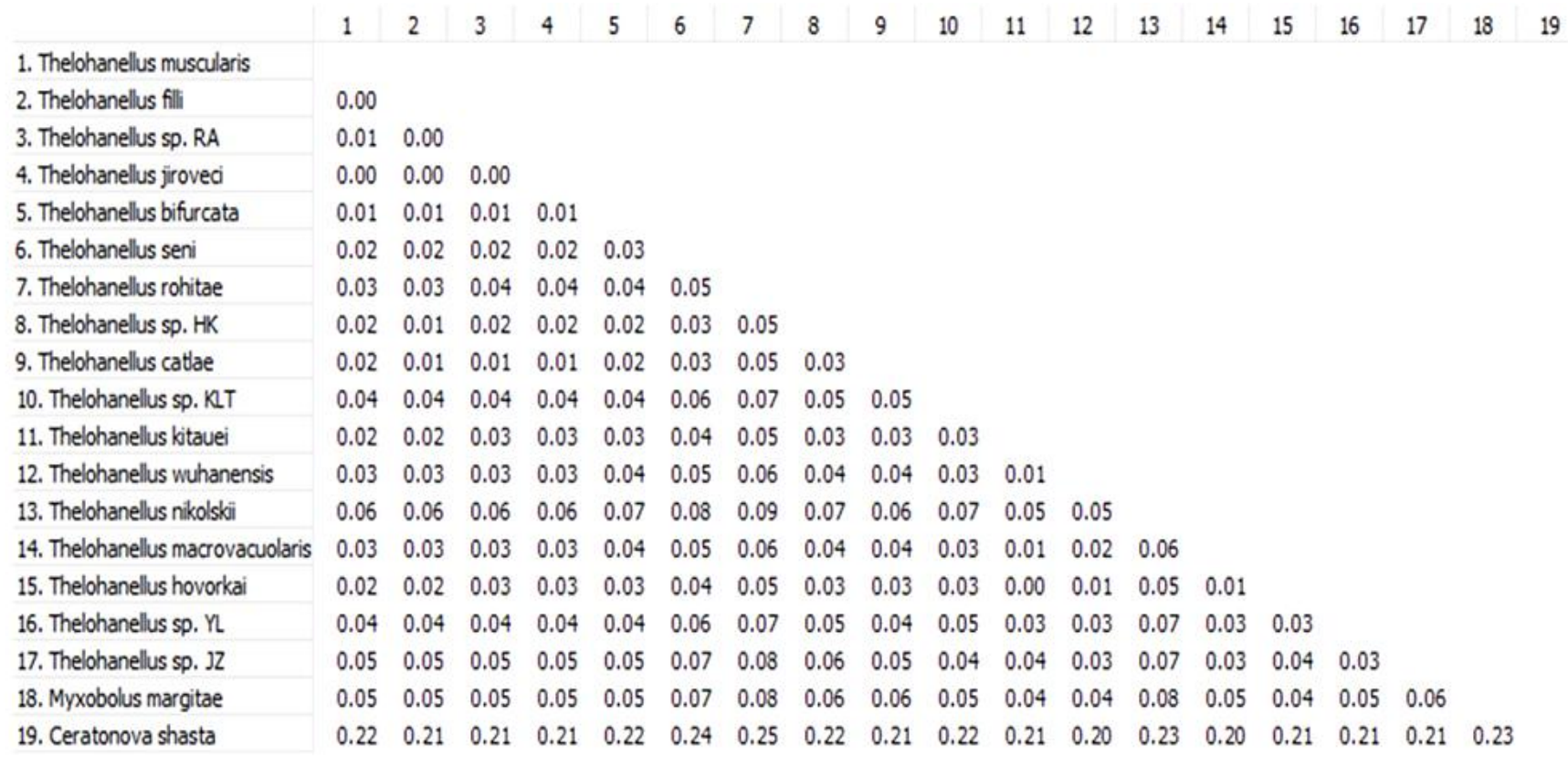

Fig. 6: Estimates of evolutionary divergence between the sequences of T. muscularis n. sp. (KT387308) and other myxosporeans available in NCBI GenBank.

\section{CONCLUSIONS}

The present study deals with the identification of a new myxosporean parasite, T. muscularis n. sp. infecting the head muscles of Labeo rohita from Ranjit sagar wetland, Punjab (India). The $18 \mathrm{~S}$ rDNA molecular marker was used to study the phylogeny of the parasite. Histopathogenesis indicated intermuscular space as the tissue location causing deformation and damage to muscle cells. The present study further supported the formation of species complex among the members of the genus Thelohanellus recorded from the same geographical location and cyprinid host.

\section{ACKNOWLEDGEMENTS}

Financial support and sponsorship: The authors acknowledge financial support by University Grants Commission (UGC), Govt. of India under CAS grant.

Conflict of Interests: There are no conflicts of interest.

\section{REFERENCES}

1. Kudo R. A taxonomic consideration of myxosporidia. Transactions of the American Microscopical Society. 1933; 52:195-216.

2. Zhang JY, Gu ZM, Kalavati C, Eiras JC, Liu Y, Guo QY, Molnár K. A synopsis of the species of Thelohanellus Kudo, 1933 (Myxozoa: Myxosporea: Bivalvulida). Systematic Parasitology. 2013; 86: 235-56.

3. Lom J, Dyková I. Myxozoan genera: definition and notes on taxonomy, life-cycle terminology and pathogenic species. Folia Parasitologica. 2006; 53:1-36.

4. Hsieh SR, Xiao C. Discovery of a myxosporidean with four valves in a freshwater fish and discussion of its taxonomic position. Asian Fishery Science. 1993; 6:239-243.
5. Akhmerov AK. Myxosporidia of fishes from the Amur River basin. Rybn. Khoz. Venutr. Vodoemov Latv. SSR. 1960; 5:240-307.

6. Akhmerov AK. Ways of the origin of myxosporidian species of the genus Thelohanellus Kudo from Amur wild carp. Doklady Akademii Nauk SSSR. 1955; 105:1129-1132.

7. Egusa S. The order multivalvulida Shulman, 1959 (Myxozoa: Myxosporea): a review. Fish Pathology. 1986; 21:261-274.

8. Zhang JY, Gu ZM, Kalavati C, Eiras JC, Liu Y, Guo QY, Molnár K. A synopsis of the species of Thelohanellus Kudo, 1933 (Myxozoa: Myxosporea: Bivalvulida). Systematic Parasitology. 2013; 86:235256.

9. Basu S, Haldar DP. Thelohanellus bifurcata $\mathrm{n}$. $\mathrm{sp}$. a new species of the genus Thelohanellus from hybrid carps and checklist of the species of the genus described from Indian fishes. Proceedings of Zoological Society of Calcutta. 1999; 52(1):115-124.

10. Kaur H, Dar SA, Singh R. One new and three already known myxosporean parasites of Indian major carps in Punjab (India). Species. 2013b; 4:17-24.

11. Wang G, Yao W, Gong X, Wang J, Nie P. Seasonal fluctuation of Myxobolus gibelioi (myxosporea) plasmodia in the gills of the farmed allogynogenetic gibel carp in China. Chinese Journal of Oceanology and Limnology. 2003; 21(2):149-153.

12. Liyanage YS, Yokoyama H, Wakabayashi H. Evaluation of vectorcontrol strategy of haemorrhagic thelohanellosis in carp, caused by Thelohanellus hovorkai (Myxozoa). Diseases of Aquatic Organisms, Vol. 55, No. 1, Jun. 2003, p. 31-35, ISSN 0177-5103.

13. Molnár K. Biology and histopathology of Thelohanellus nikolskii Akhmerov,1955 (Myxosporea, Myxozoa), a protozoan parasite of the common carp (Cyprinus carpio). Zeitschrift für Parasitenkunde. 1982; 68:269-277.

14. Kaur H, Katoch A. Gill disease caused by Thelohanellus bifurcata Basu and Haldar, 1999 a pathogenic myxozoan parasite in cultured Indian carp, Labeo rohita (Hamilton, 1822) in Punjab, India. Journal of Animal Health and Production. 2014; 2(2):19-24.

15. Kumar A, Qureshi TA, Prashar A, Patiyal RS. Seasonal variation in physico-chemical characteristics of Ranjit Sagar reservoir, Jammu \& Kashmir. Journal of Ecophysiology and Occupational Health. 2006; 6(3\&4):143-147. 
16. Kaur H, Gupta A. Genetic relatedness provides support for a species complex of myxosporeans infecting the Indian major carp, Labeo rohita. Animal Biology. 2015; 65 (3):337-347.

17. Atkinson SD, Bartošová-Sojková $\mathrm{P}$, Whipps $\mathrm{CM}$, Bartholomew JL. Approaches for Characterising Myxozoan Species. In Myxozoan Evolution, Ecology and Development. (eds. Okamura et al. ), Springer International Publishing Switzerland; 2015, p. 111-123.

18. Kaur H, Singh R. Observations on one new species of genus Myxobolus - M. naini and rediscription of M. magauddi recorded from freshwater fishes of Kanjali Wetland of Punjab, India. Proceedings of $20^{\text {th }}$ National Congress of Parasitology. NEHU Shillong, India. 2008, p. 75-79.

19. Kaur H, Singh R. A new myxosporean species, Myxobolus eirasi sp. nov., a known species M. venkateshi Seenappa and Manohar (1981) from the Indian major carp fish Cirrhina mrigala (Ham). Protistology. 2009; 6:126-130.

20. Kaur H, Singh R. One new myxosporidian species, Myxobolus slendrii sp. nov., and one known species, M. punjabensis Gupta and Khera, 1989, infecting freshwater fishes in wetlands of Punjab, India. Parasitolology Research. 2010a; 106(5):1043-1047.

21. Kaur H, Singh R. A new myxosporean species Myxobolus sclerii sp. nov. and one known species M. stomum Ali et al. (2003) from two Indian major carp fishes. Journal of Parasitic Diseases. 2010b; 34:3339.

22. Kaur H, Singh R. Two new species of Myxobolus (Myxozoa: Myxosporea: Bivalvulida) from freshwater fishes of Punjab wetlands (India). Journal of Parasitic Diseases. 2011a; 35:33-41.

23. Kaur H, Singh R. Two new species of Myxobolus (Myxozoa: Myxosporea: Bivalvulida) infecting an Indian major carp in Ropar and Kanjali wetlands (Punjab). Journal of Parasitic Diseases. 2011b; 35(1):23-32.

24. Kaur H, Singh R. Two new species of Myxobolus (Myxozoa: Myxosporea: Bivalvulida) infecting an Indian major carp and a cat fish in wetlands of Punjab, India. Journal of Parasitic Diseases. 2011; $35: 169-176$.

25. Kaur H, Singh R. Two new species of Myxobolus (Myxozoa: Myxosporea: Bivalvulida) infecting Indian freshwater fishes in Punjab wetlands (India). Parasitology Research. 2011; 108:1075-1082.

26. Kaur H, Singh R. Myxobolus harikensis sp. nov. (Myxozoa: Myxobolidae) infecting fins of Cirrhina mrigala (Ham.), an Indian major carp in Harike wetland, Punjab (India). Parasitology Research 2011; 109:1699-1705.

27. Kaur H, Singh R. Two new and one already known species of Myxobolus (Myxozoa: Myxosporea: Bivalvulida) infecting gill lamellae of Indian major carp fishes in Ropar and Harike wetlands (Punjab). Proceedings of $22^{\text {nd }}$ National Congress of Parasitology, Kalyani University, West Bengal, India. 2011f, p. 81-90.

28. Kaur H, Singh R. A synopsis of the species of Myxobolus Bütschli, 1882 (Myxozoa: Bivalvulida) parasitizing Indian fishes and a revised dichotomous key to myxosporean genera. Systematic Parasitology. 2012a; 81:17-37.

29. Kaur H, Singh R. One new myxosporean species, Triangula cirrhini sp. n., and one known species, T. ludhianae (syn. M. ludhianae Gupta and Khera, 1991) comb. n. (Myxozoa: Myxosporea), infecting Indian major carp in Harike wetland of Punjab. Animal Biology. 2012b; 62:129-139.

30. Singh R, Kaur H. Thelohanellus (Myxozoa: Myxosporea: Bivalvulida) Infections in major carp fish from Punjab wetlands (India). Protistology. 2012a; 7:178-188.

31. Singh R, Kaur H. Two new Thelohanellus Kudo, 1933 (Myxozoa: Myxosprea: Bivalvulida) infecting fins of major carps in wetlands of Punjab. Trends in Parasitology Research. 2012b; 1(3):34-43.

32. Singh R, Kaur H. Myxosporean species of the genus Thelohanellus Kudo, 1933 (Myxozoa: Myxosprea: Bivalvulida) from freshwater fishes of Punjab wetlands, India. Protistology. 2012c; 7(4):208-217.

33. Singh R, Kaur H. Two new and two already known species of genus Thelohanellus Kudo, 1933 (Myxozoa: Myxosporea: Bivalvulida) infecting Indian major carp fishes in Punjab wetlands (India). Journal of Parasitic Diseases. 2014; 38(1):49-60.
34. Singh R, Kaur H. Two new and one already known species of the genus Thelohanellus Kudo, 1933 (Myxozoa: Myxosporea: Bivalvulida) parasitizing fresh water fishes in wetlands of Punjab, India. Animal Biology. 2015; 70(1):85-93.

35. Kaur H, Dar SA, Singh R. A report on three Myxozoan parasites causing gill myxoboliosis in aquaculture fishes in Punjab (India) Trends in Parasitology Research. 2013a; 1:1-6.

36. Kaur H, Dar SA, Singh R. One new and three already known myxosporean parasites of Indian major carps in Punjab (India). Species. 2013b; 4:17-24.

37. Kaur H. Dar SA, Katoch A. Thelohanellus dykovi sp. nov. (Myxozoa: Bivalvulidae), a pathogenic gill parasite in cultured Indian major carp, Labeo rohita (Hamilton 1822) in Punjab (India). Species. 2014a; 10(23):24-30.

38. Kaur H, Katoch A, Gupta M. Thelohanellus filli sp. n., a pathogenic myxosporean infecting gills of cultured carp, Labeo rohita (Hamilton 1822) in Punjab, India. Species. 2014b; 10(23):31-38.

39. Kaur H, Attri R. Morphological and molecular characterization of Henneguya bicaudi n. sp. (Myxosporea: Myxobolidae) infecting gills of Cirrhinus mrigala (Ham.) in Harike Wetland, Punjab (India). Parasitology Research. 2015a; DOI 10.1007/s00436-015-4647-0.

40. Luna LG. Manual of histologic staining method of the Armed Forces Institute of Pathology. 1968, p. 111.

41. Andree KB, Shekels C, Molnár K, Gresoviac SJ, Hedrick RP. Relationship among members of the genus Myxobolus (Myxozoa: Bivavulida) based on small subunit ribosomal DNA sequences. Journal of Parasitology. 1999; 85:68-74.

42. Fiala I. The phylogeny of Myxosporea (Myxozoa) based on small subunit ribosomal RNA gene analysis. International Journal of Parasitology. 2006; 36:1521-1534.

43. Kimura M. A simple method for estimating evolutionary rate of base substitutions through comparative studies of nucleotide sequences. Journal of Molecular Evolution. 1980; 16, 111-120.

44. Tamura K, Peterson D, Peterson N, Stecher G, Nei M, Kumar S. MEGA6: Molecular evolutionary genetics analysis using maximum likelihood, evolutionary distance, and maximum parsimony methods. Molecular Biology and Evolution. 2013; 28:2731-2739.

45. Ronquist F, Huelsenbeck JP. Bayesian phylogenetic inference under mixed models. Biogeosciences. 2003; 19:1572-1574.

46. Dykovà I. Light and Microscopic studies of Myxobolus longisporus (Myxozoa: Myxobolidae), a gill infecting parasites of carp, Cyprinus carpio haematopterus from chinese lakes. Folia Parasitologica. 2003; 50:263-268.

47. Molnár K, Eszterbauer E. Specificity of infection sites in vertebrate hosts. In: Myxozoan evolution, ecology and development (eds. B Okamura, A. Gruhl and J.L. Bartholomew). Springer International Publishing Switzerland, 2015, p. 295-313.

48. Chakravarty M, Basu MS. Observations on some myxosporidians parasitic in fishes, with an account of nuclear cycles in one of them. Proceedings of Zoological Society of Bengal. 1948; 1:23-33.

49. Qadri SS. A new myxosporidian Thelohanellus boggoti $\mathrm{n}$. sp. from an Indian fresh water fish Labeo boggot. Archiv fur Protistenkunde. $1962 b ; 106: 218-222$.

50. Lalitha Kumari PS. Studies on parasitic protozoa (Myxosporidia) of fresh water fishes of Andhra Pradesh, India. Riv Parasitology. 1969; 30:153-226

51. Allamuratov B. New species of parasitic protozoa found in the fish of South-Surkham Reservoir. Uzbekskii Biologicheskii Zhurnal. 1966; 10:58-60.

52. Kundu TK, Haldar DP. Studies in Thelohanellus jiroveci sp. nov. a new myxosporidian parasite in a common teleost fish. Vest. Cesk. Spol. Zool. 1981; 45:94-101.

53. Sarkar NK. Some coelozoic Myxosporida (Myxozoa: Myxosporea) from a freshwater water teleost fish of River Padma. Acta Protozoologica. 1985b; 24(1):47-53.

54. Narasimhamurti CC, Kalavati C, Anuradha I, Padma Dorothy K. Studies on the protozoan parasites of deep water fish from the Bay of Bengal. Proceedings of Second Workshop on Scientists. Results of FORV Sagar Sampada, 1990, p. 325-336. 
55. Pagarkar AU, Das M. Two new species of myxozoa, Thelohanellus caudatus n. sp. and Myxobolus serrata n. sp. from cultural carps. Journal of Inland Fishery Society of India. 1993; 25(1):30-35.

56. Tripathi YR. Some new Myxosporidia from Plymouth with a proposed new classification of the order. Journal of Parasitology. 1948; 39:110118.

57. Haldar DP, Das MK, Sharma, BK. Studies on Protozoan parasites from fishes. Four new species of the genera Henneguya Thelohan, 1882, Thelohanellus Kudo, 1933, and Myxobolus Butschli, 1882. Arch Protistenk. 1983; 127:283-296.

\section{How to cite this article:}

Kaur H, Gupta A. Morphological, histopathological and molecular characterization of Thelohanellus muscularis $\mathrm{n}$. sp. (Cnidaria: Myxosporea) infecting head muscles of Labeo rohita from Ranjit sagar wetland, Punjab (India). J App Biol Biotech. 2017; 5 (01): 021-028. DOI: 10.7324/JABB.2017.50104 